\title{
Detection and molecular characterization of Shiga toxin producing Escherichia coli (STEC) autoagglutinating adhesion gene (saa) from piglets in Mizoram
}

\author{
J. L. Kataria, T. K. Dutta, P. Roychoudhury and J. G. Tiwari
}

\begin{abstract}
College of Veterinary Sciences and Animal Husbandry, Central Agricultural University, Aizawl, Mizoram- 796014
Corresponding auhtor: T. K. Dutta, email: tapandutta@rediffmail.com, JLK: jluvjkat@gmail.com,

TKD: tapandutta@rediffmail.com, PR: parimal74@rediffmail.com, JGT: tapandutta72@yahoo.com

Received: 02-04-2014, Revised: 01-05-2014, Accepted: 06-05-2014, Published online: 04-06-2014
\end{abstract}

doi: 10.14202/vetworld.2014.373-376 How to cite this article: Kataria JL, Dutta TK, Roychoudhury P and Tiwari JG (2014) Detection and molecular characterization of Shiga toxin producing Escherichia coli (STEC) autoagglutinating adhesion gene (saa) from piglets in Mizoram, Veterinary World 7(6): 373-376.

\begin{abstract}
Aim: The study was carried out to detect and characterize the Shiga toxin producing Escherichia coli (STEC) auto agglutinating adhesion gene ( $s a a)$ from Piglets in Mizoram.

Materials and Methods: A total 100 fecal samples from 0-3 month old piglets with (60) or without (40) diarrhoea were collected from different parts of Mizoram and screened for the presence of $E$. coli. All the locus of enterocyte (LEE) negative STEC strains was tested for the presence saa gene by polymerase chain reaction (PCR).

Results: In this study, a total of $254 \mathrm{E}$. coli isolated and identified. Altogether, $51 \mathrm{E}$. coli were found to be positive for at least one virulence gene tested, of which 30 and 21 were classified as STEC and EPEC, respectively. A total of 4 E. coli isolates were found to be positive for saa gene, of which one was from diarrhoeic and three were from healthy piglets.
\end{abstract}

Conclusions: STEC and EPEC are prevalent in pig population of Mizoram. Presence of saa gene positive E. coli in pigs in this region may pose a threat to public health.

Keywords: locus for enterocyte effacement, STEC autoagglutinating adhesion, Shigatoxigenic Escherichia coli, STEC.

\section{Introduction}

Shiga-toxin producing Escherichia coli (STEC) are serologically diverse, emerging food borne pathogens and leading cause for a spectrum of human illness ranging from haemorrhagic diarrhoea to even fatal consequences such as hemolytic uraemic syndrome (HUS), thrombotic thrombocytopenic purpurea (TTP) and haemorrhagic colitis (HC) $[1,2,3]$. STEC infection is commonly acquired through the consumption of faecal contaminated food or water, through direct or indirect contact with animal carriers or via secondary person to person transmission [4]. Healthy domestic ruminants are recognised as the main natural reservoir of STEC and large game animal maybe healthy carriers of STEC [5, 6]. Fresh meat and ready-to-eat meat products obtained from deer have been implicated in food borne transmission of STEC to humans in United States [7, 8]. In May 2011, strains belonging to the hitherto rarely detected STEC serotype O104:H4 were identified as causative agents of one of the world's largest outbreak of disease with high incidence of $\mathrm{HC}$ and HUS in the infected patients [9].

The STEC family is very diverse, and strains belonging to a broad range of $\mathrm{O}: \mathrm{H}$ serotypes have been associated with human diseases. However, epidemiological evidence indicates that certain STEC subsets (for example, strains belonging to serotype

Copyright: The authors. This article is an open access article licensed under the terms of the Creative Commons Attribution License (http://creativecommons.org/licenses/by/2.0) which permits unrestricted use, distribution and reproduction in any medium, provided the work is properly cited.

Veterinary World, EISSN: 2231-0916
O157:H7) account for a disproportionately large number of serious infections. STEC strains produce one or both of two major types of Shiga toxin, designated $\mathrm{Stx}_{1}$ and $\mathrm{Stx}_{2}$, and the production of the latter is associated with an increased risk of developing HUS. In addition, a subset of STEC strains considered to be highly virulent for humans has the capacity to produce attaching and effacing lesions on intestinal mucosa, a property encoded on a pathogenicity island termed the locus for enterocyte effacement (LEE). LEE encodes a type III secretion system and E. coli secreted proteins, which deliver effector molecules to the host cell and disrupt the host cytoskeleton. LEE also carries eae, which encodes an outer membrane protein (intimin) required for intimate attachment to epithelial cells; eae has been used as a convenient diagnostic marker for LEE positive STEC strains. However, the presence of eae is not absolutely linked to human virulence, as some sporadic cases of severe STEC disease, including HUS, as well as occasional outbreaks have been caused by LEE-negative strains $[10,11]$.

Recently, another virulence gene has been reported as STEC autoagglutinating adhesion gene ( $s a a)$, which is carried on the large plasmid of certain LEE negative strains and this genes encode a novel outer membrane protein, which functions as an adhesin $[12,13,14]$. Till date, only two reports are available on detection of saa gene, one from captive Yaks $[15,16]$ and another from sheep [17].

To the recent knowledge of the authors, no report 
Table-1: Details of the oligonucleotide primers used in the present study-

\begin{tabular}{|c|c|c|c|}
\hline Primer & Sequence & Amplicon size & Reference \\
\hline stx1F & 5 ATAAATCGCCATTCGTTGACTAC-3 & & \\
\hline$s t \times 1 R$ & 5'AGAACGCCCACTGAGATCATC-3 & $180 \mathrm{bp}$ & [20] \\
\hline st $\times 2 F$ & 5 'GGCACTGTCTGAAACTGCTCC-3 & & \\
\hline$s t \times 2 R$ & 5'TCGCCAGTTATCTGACATTCTG-3' & $255 \mathrm{bp}$ & [20] \\
\hline eaeAF & 5 GACCCGGCACAAGCATAAGC-3 & & \\
\hline eaeAR & 5'CCACCTGCAGCAACAAGAGG-3 & $384 \mathrm{bp}$ & [20] \\
\hline hlyAF & 5 GCATCATCAAGCGTACGTTCC-3' & & \\
\hline hlyAR & 5'AATGAGCCAAGCTGGTTAAGCT-3 & $534 b p$ & [20] \\
\hline saaF & 5 CGTGATGAACAGGCTATTGC-3 & & \\
\hline saaR & 5'ATGGACATGCCTGTGGCAAC-3 & $119 \mathrm{bp}$ & [19] \\
\hline
\end{tabular}

has been published on association of saa gene in pigs in India. So, the present study was conducted to detect the saa gene in $E$. coli isolated from piglets in Mizoram.

\section{Materials and Methods}

Ethical approval: The present study was approved by the Institutional Animal Ethics Committee vide Order No. CVSC/CAU/IAEC/11-12/R17.

Sampling and isolation of E. coli: In the present study 100 fecal samples originating from 40 healthy and 60 diarrhoeic piglets (0-3 month) were collected from different parts of Mizoram, India. The samples were collected directly from rectum using swabs and processed immediately by inoculating on Mac Conkeys Agar (Hi-Media, Mumbai, India) plates. After 24 hours incubation at $37^{\circ} \mathrm{C}$, five rose pink colonies were randomly picked up and subcultured on eosin methylene blue (EMB) agar (Hi-Media, Mumbai, India) plates to observe the metallic sheen characteristics of $E$. coli. A well separated presumptive $E$. coli single colony was picked up on nutrient agar slants as pure culture and subjected to standard morphological and biochemical testing as described by Ewing [18].

Templates DNA preparation: The E. coli isolates confirmed by conventional tests were grown in Luria Bertani broth (Hi-media, Mumbai, India) at $37^{\circ} \mathrm{C}$ overnight. One $\mathrm{ml}$ of the broth culture was pelleted by centrifugation at $8000 \mathrm{rpm}$ for 10 minutes, washed twice with $500 \mu \mathrm{l}$ of PBS ( $\mathrm{pH} 7.4)$. The bacterial pellet was finally, re-suspended in $300 \mu 1$ sterile nuclease free water and lysed by boiling for 10 minutes in a water bath followed by immediate chilling for 10 minutes on ice. The lysates were centrifuged again at $6000 \mathrm{rpm}$ for 10 minutes and the supernatant was used as template DNA.

Detection of STEC and Enteropathogenic Escherichia coli (EPEC) marker genes and saa gene by PCR: A multiplex Polymerase chain reaction (PCR) was carried out using four sets of oligonucleotide primers for $s t x_{1}, s t x_{2}, e a e A$ and $h l y A$ genes (Table-1) and all the LEE negative STEC strains were further tested for the presence saa gene (Table-1). The PCR protocol was followed as per the method described in previous works $[19,20]$ with slight modification. The multiplex PCR mixture of $25 \mu \mathrm{l}$ contained $1 \mathrm{X}$ PCR buffer, 1.5 $\mathrm{mM}$ of $\mathrm{MgCl}_{2}, 40 \mathrm{nM}$ of primer, $200 \mu \mathrm{M}$ dNTPs, $1.0 \mathrm{U}$ of Taq DNA polymerase and $2.0 \mu \mathrm{l}$ of template DNA.
The PCR reaction was performed in a thermal cycler (Thermo Electron, Germany) using the following standard cycling procedure: an initial denaturation at $95^{\circ} \mathrm{C}$ for $5 \mathrm{~min}$, followed by 30 cycles of denaturation at $94^{\circ} \mathrm{C}$ for $45 \mathrm{sec}$, primer annealing at $65^{\circ} \mathrm{C}$ for $45 \mathrm{sec}$ and extension at $72^{\circ} \mathrm{C}$ for $42 \mathrm{sec}$ and a final extension at $72^{\circ} \mathrm{C}$ for $5 \mathrm{~min}$.

Amplified products were analyzed by agarose gel ( $2 \%$ in $1 \mathrm{X} \mathrm{TBE}$ ) electrophoresis at $5 \mathrm{v} / \mathrm{cm}$ for $2 \mathrm{~h}$ and documented using gel documentation system (Alpha imager, Germany).

\section{Results}

Bacterial isolation: A total of $254 \mathrm{E}$. coli strains were isolated from 100 faecal samples collected from piglets, of which 132 isolates were from piglets with diarrhoea (60) and 122 from non-diarrhoeic piglets (40).

PCR for STEC and EPEC genes: Of $254 \mathrm{E}$. coli isolates tested for 4 virulence genes (stx, st $x_{2}$, eaeA and hlyA), $51(20.08 \%)$ were carried at least 1 virulence gene, of which $30(11.81 \%)$ and $21(8.26 \%)$ were detected as STEC and EPEC, respectively. Of 21 EPEC isolates, $17(80.95 \%)$ isolates carried both $h l y \mathrm{~A}$ and eae $A$ genes and $4(19.05 \%)$ carried eaeA gene only. A total of $2(0.78 \%), 9(3.54 \%), 2(0.78 \%), 7(2.75 \%), 1(0.39 \%)$, 9(3.54\%), 4(1.57\%), 17(6.69\%) E. coli isolates were carried $s t x_{1}$ only, stx $x_{2}$ only, stx $x_{1}$ and $s t x_{2}, s t x_{2}$ and eaeA, $s t x_{2}$ and $h l y \mathrm{~A}, s_{2} x_{2}$,eaeA and $h l y \mathrm{~A}, s_{2} x_{2}$,eaeA and $h l y \mathrm{~A}$, eae and $h l y \mathrm{~A}$, respectively. None of the isolates were carried hlyA gene only.

PCR for saa gene: The PCR assay yielded amplified products of $119 \mathrm{bp}$, specific for saa genes (Figure-1). In this study, a total of four $(1.5 \%)$ E. coli strains were found to be positive for saa gene of which three were from healthy piglets and one was from diarrhoeic piglet. Out of four saa gene positive strains, stx $x_{1}$ gene was detected in two isolates, whereas, other two isolates were positive for both stx $x_{1}$ and st $x_{2}$ genes.

\section{Discussion}

This study, reports for the first time the detection and characterization of saa genes among piglets with or without diarrhoea in Mizoram. Till now, in India there are only two reports on detection of saa gene, one from captive Yaks [15, 16] and another from sheep [17]. They have reported the presence of saa gene in $20.63 \%$ fecal samples from captive Yaks and 44\% 


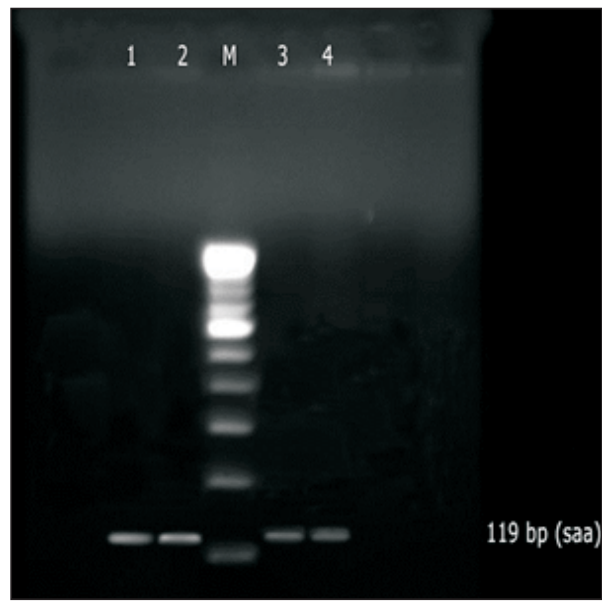

Figure-1: saa gene specific PCR analysis of STEC isolates. Lane 1: saa positive, Lane 2: saa positive, Lane M: Marker (100bp), Lane 3: saa positive, Lane 4: saa positive

samples from sheep. In every case, it was associated with $s t x_{1}$, stx 2 and $e h x$ genes.

Liu et al. [21] could not detect any saa gene from 206 isolates obtained from suckling pigs with diarrhea in China. Prevalence of saa gene in buffalo was $8 \%$ [22] and $83 \%$ [23].

The saa gene is present exclusively in LEEnegative STEC strains as reported in Yaks [15], sheeps [17], buffaloes [22, 23] and humans [19]. They have also indicated a strong association of saa and $e h x$ genes in eaeA negative strains of different serotypes.

Our result indicates the non-association of eaeA and $s a a$ genes, which was in accordance to result with the above workers and at the same time it was showing the difference in association of $s a a$ and $e h x$ genes, which can be explained by the high variability of the large STEC plasmids [24] and this result was in accordance to the result of Beraldo et al. [25], who found that there was no correlation between $s a a$ and $e h x$ genes. It is possible that $e h x$ gene is not located on the same plasmid as saa.

The saa genes encode a novel outer membrane protein, which appears to function as an autoagglutinating adhesion and the introduction of cloned saa confers a semi localized adherence phenotype on E. coli K12 strains [26]. saa gene has been recorded from a variety of pathogenic LEE negative STEC strains from HUS cases from different parts of the world [19]. It is, therefore possible that saa is a marker for the hitherto ill-defined subset of LEE negative STEC strains capable of causing life threatening disease in humans [20]. Further studies to be carried out to examine the role of saa gene associated with diarrhoea in piglets.

\section{Conclusion}

STEC and EPEC are prevalent in healthy and diarrhoeic pig populations of Mizoram. Presence of saa gene in EPEC isolates increases the probability of piglet diarrhoea as it helps in $\mathrm{AE}$ lesions. It is also a public health concern in the region.

\section{Authors' contributions}

JLK and TKD planned and designed the study, JLK, JGT and PR performed the research experiment. JLK and TKD drafted and revised the manuscript. All authors read and approved the final manuscript.

\section{Acknowledgements}

The authors are highly thankful to Dean, College of Veterinary Science and Animal Husbandry, Central Agricultural University, Selesih, Aizawl, Mizoram, India for providing necessary funds and facilities to carry out the investigation.

\section{Competing interests}

The authors declare that they have no competing interests.

\section{References}

1. Croxen, M.A. and Finlay, B.B. (2010) Molecular mechanisms of Escherichia coli pathogenicity. Nat. Rev. Microbiol. 8: 26-38.

2. Gyles, C.M. and Fairbrother, J.M. (2010) Escherichia coli. In: Gyles, C.L., Prescott, J.F., Thoen, C.O. (Eds.), Pathogenesis of Bacterial Infections in Animals. Blackwell Publishing, Ames, p267-308.

3. Sanchez, S., Sanchez, D.S., Martinez, R., Llorente, M.T., Herrera-Leon, S and Vidal, D. (2013) The new allelic variant of the subtilase cytotoxin $\left.(\operatorname{subAB})_{2}\right)$ is common among Shiga toxin producing Escherichia coli strains from large animals and their meat and meat products. Vet. Microbiol. 166: 645649.

4. Caprioli, A., Morabito, S., Brugere, H. and Oswald, E. (2005) Enterohaemorrhagic Escherichia coli: emerging issues on virulence and modes of transmission. Vet. Res. 36: 289-311.

5. Diaz, S., Vidal, D., Herrera-Leon, S. and Sanchez, S., (2011) Sorbitol-fermenting, b-glucuronidase-positive, Shiga toxinnegative Escherichia coli O157:H7 in free-ranging red deer in South-Central Spain. Foodborne Pathog. Dis. 8: 13131315.

6. Sanchez, S., Martınez, R., Garcia, A., Vidal, D., Blanco, J., Blanco, M., Blanco, J.E., Mora, A., Herrera-Leon, S., Echeita, A., Alonso, J.M. and Rey, J. (2010) Detection and characterization of O157:H7 and non-O157 Shiga toxinproducing Escherichia coli in wild boars. Vet. Microbiol. 143: 420-423.

7. Ahn, C.K., Russo, A.J., Howell, K.R., Holt, N.J., Sellenriek, P.L., Rothbaum, R.J., Beck, A.M., Luebbering, L.J. and Tarr, P.I. (2009) Deer sausage: a newly identified vehicle of 
transmission of Escherichia coli O157:H7. J. Pediatr. 155: 587-589.

8. Rounds, J.M., Rigdon, C.E., Muhl, L.J., Forstner, M., Danzeisen, G.T., Koziol, B.S., Taylor, C., Shaw, B.T., Short, G.L. and Smith, K.E. (2012) Non-O157 Shiga toxinproducing Escherichia coli associated with venison. Emerg. Infect. Dis. 18:279-282.

9. European Food Safety Authority. (2011) Shiga toxinproducing E. coli (STEC) O104:H42011 outbreaks in Europe: taking stock. EFSA J. 9: 2390.

10. Boerlin P., McEwen S.A., Boerlin-Petzold F., Wilson J.B., Johnson R.P. and Gyles C.L. (1999). Associations between virulence factors of Shiga toxin-producing Escherichia coli and disease in humans. J. Clin. Microbiol.37:497-503.

11. Scheutz, F., Teel, L.D., Beutin, L., Pierard, D., Buvens, G., Karch, H., Mellmann, A., Caprioli, A., Tozzoli, R., Morabito, S., Strockbine, N.A., Melton-Celsa, A.R., Sanchez, M., Persson, S. and O'Brien, A.D. (2012) Multicenter evaluation of a sequence-based protocol for subtyping Shiga toxins and standardizing Stx nomenclature. J. Clin. Microbiol. 50: 2951-2963.

12. Wani S.A., Samanta I., Bhat M.A. and Nishikawa Y. (2004) Investigation of Shiga toxin- producing Escherichia coli in avian species in India. Lett. Appl. Microbiol. 39:389-94.

13. Gyles, C.L. (2007) Shiga toxin-producing Escherichia coli: an overview. J. Anim Sci. 85 E45eE62.

14. Toledo, A., Gomez, D., Cruz, C., Carreon, R., Lopez, J., Giono, S. and Castro, A.M. (2012) Prevalence of virulence genes in Escherichia coli strains isolated from piglets in the suckling and weaning period in Mexico. J. Med. Microbiol. 61: 148-156.

15. Bandyopadhyay, S., Biswas, T.K., Sasmal, D., Ghosh, M.K., Dutta, T.K., Das, S.C., Pan, D., Bhattacharya, D., Bera, A.K., Bandyopadhyay, S. and De, S. (2009) Virulence gene and antibiotic resistance profile of Shiga-toxin producing Escherichia coli prevalent in captive yaks (Poephagus grunniens). Vet. Microbiol. 138: 403-404.

16. Bandyopadhyay, S., Lodh, C., Rahaman, H., Bhattacharya, D., Bera, A.K., Ahmed, F.A., Mahanti, A., Samanta, I., Mondal, D.K., Bandyopadhyay, S., Sarkar, S., Dutta T.K., Maity, S., Paul, V., Ghosh, M.K., Sarkar, M. and Baruah, K.K. (2012) Characterization of shiga toxin producing (STEC) and enteropathogenic Escherichia coli (EPEC) in raw yak (Poephagus grunniens) milk and milk products. Res. Vet. Sc. 93: 604-610.

17. Bandyopadhyay, S., Mahanti, A., Samanta, I., Dutta, T.K.,
Ghosh, M.K., Bera, A.K., Bandyopadhyay, S. and Bhattacharya, D. (2011) Virulence repertoire of Shiga toxin producing Escherichia coli (STEC) and Enterotoxigenic Escherichia coli (ETEC) from diarrhoeic lambs of Arunachal Pradesh India. Trop. Anim. Health. Prod. 43: 705-710.

18. Ewing, W.H. (1986) The genus Escherichia, In P. R. Edwards and W. H Ewing (ed), Edwards and Ewing's identification of Enterobacteriaceae, $4^{\text {th }}$ ed. Elsevier Science Publishing Co Inc., New York, p93-122.

19. Paton, A.W., Srimanote, P., Woodrow, M.C. and Paton, J.C. (2001) Characterization of saa, a novel autoagglutinating adhesin produced by locus of enterocyte effacementnegative Shiga-toxigenic Escherichia coli strains that are virulent for humans. Infect. Immun. 69: 6999-7009.

20. Paton A. W. and J. C. Paton. (2002). Direct detection and characterization of Shiga toxigenic Escherichia coli strains by multiplex PCR for stx 1, stx2, eae, ehxA, and saa.J. Clin. Microbiol.40:271-274.

21. Liu, W., Yuan, C., Meng, X., Du, Y., Gao, R., Tang, J. and Shi, D. (2014) Frequency of virulence factors in Escherichia coli isolated from suckling pigs with diarrhoea in China. Vet. $J$. 199: 286-289.

22. Islam, M.A., Mondol, A.S., de Boer, E., Beumer, R.R., Zwietering, M.H., Talukder, K.A. and Heuvelink, A.E. (2008) Prevalence and genetic characterization of Shiga toxin-producing Escherichia coli isolates from slaughtered animals in Bangladesh. Appl. Environ. Microbiol. 74: 54145421.

23. Oliveira, M.G., Feitosa Brito, J.R., Carvalho, R.R., Guth, B.E.C., Gomes, T.A.T., Vieira, M.A.M., Kato, M.A.M.F., Ramos, I.I., Vaz, T.M.I. and Irino, K. (2007) Water buffaloes (Bubalus bubalis) identified as an important reservoir of Shiga toxin-producing Escherichia coli in Brazil. Appl. Environ. Microbiol. 73: 5945-5948.

24. Brunder W., H. Schmidt, and Karch, H. (1997). EspP, a novel extracellular serine protease of enterohaemorrhagic Escherichia coli $\mathrm{O} 157: \mathrm{H} 7$ cleaves human coagulation factor. Vet.Mol. Microbiol.24:767-778.

25. Beraldo, L.G., Borges, C., Maluta, R.P., Cardozo, M.V., Rigobelo, E.C. and Avila, F. A. (2014) Detection of Shiga toxigenic (STEC) and enteropathogenic (EPEC) Escherichia coli in dairy buffalo. Vet. Microbiol. http://dx.doi.org/10.1016/j.vetmic.2014.01.023.

26. Nataro, J.P. and Kaper, J.B. (1998) Diarrheagenic Escherichia coli. Clin. Microbiol. Rev. 11: 142-20. 